\title{
Leadership, Belonging, and National Security in the 2012 Presidential Race
}

\author{
Heather Hurlburt
}

Published online: 21 August 2012

(C) Springer Science+Business Media, LLC 2012

National security has already played a greater-than-expected role in this campaign, for three reasons, only one of which has much to do with the way the United States conducts its relations with foreign countries. First, the political establishment is re-fighting a 2008 battle about how the United States should lead in the world, and its proper mix of engagement versus unilateralism. Second, with President Obama showing his strongest policy marks on national security, his campaign was eager to make the issue a demonstrator of leadership; Republicans have gone after the issue, in turn, following the maxim "Attack your enemy where he is strong." Finally, from the Yellow Peril to the Red Menace to 1970s Japan-bashing, the world beyond our shores has long served as a convenient source of bogeymen, and target of hostility, during times of economic hardship and cultural uncertainty. An extended recession, rapid cultural changes, perceived terrorist threats from abroad, a president with dark skin and an unusual name - all these make international fear-mongering almost inevitable.

Not just that national security is playing, but how it is playing is worthy of note: for the first time in four decades, a Democratic candidate starts the race with the advantage on the issue; history suggests that Republican determination to attack this strength, not cede it, may well pay off. More broadly, the issue plays as a surrogate for questions about "leadership" and belonging, as indeed it has throughout U.S. history, though now through new prisms in a post-post-9/11 world, and with growing implications for how any President can govern.

\section{H. Hurlburt $(\square)$}

National Security Network,

1225 'Eye' Street, suite 307,

Washington, DC 20005, USA

e-mail: hhurlburt@nsnetwork.org

\section{Re-Litigating the Foundations of U.S. Global Engagement}

The 2008 elections presented a fairly clear choice on national security policy: Senator McCain suggesting that extremist terrorism was "the central threat of our time," a threat that consisted of a nucleus of state and non-state entities who could not be subdued by anything short of force, and whom it was dangerous to try to placate; and Senator Obama, pledging to combat terrorism among a list of other threats, end the wars, and use "all the tools in the tool box" to deal with adversaries, including, most famously, negotiating with Iran.

The general public seems to think the question was settled, and to be happy with the results: Obama's national security marks in general are higher than his marks on domestic policies; specifically, the public broadly supports (http://www.washingtonpost.com/wp-srv/politics/polls/ postabcpoll_031012.html) U.S. troops exiting both Iraq and Afghanistan, and has continued to say that sanctions and negotiations, not immediate military strikes, should drive U.S. Iran policy.

Inside the Beltway, the reality is more complicated. Since Obama's first week in office, and its executive orders restricting interrogation techniques and opening a process aimed at closing the Guantanamo Bay detention center, neoconservative intellectuals and their Congressional champions have mounted a strong counter-offensive. They have claimed one symbolic but significant victory: Guantanamo Bay is still open, an outcome with which $70 \%$ of the public now supports (http://www.washingtonpost.com/politics/ poll-finds-broad-support-for-obamas-counterterrorismpolicies/2012/02/07/gIQAFrSEyQ story.html?hpid=z3) reversing the support of both presidential candidates and the public, $46 \%$-39 \% in February 2009 (http://www. people-press.org/question-search/?qid=1745074\&pid=51\& ccid=51\#top). 
But their targets are larger - reversing the pragmatic "reset" policy with Russia, and attendant arms control treaties and missile defense policy changes; confronting China more sharply; and, above all, upping the ante with Iran, and maintaining, in the face of budget pressures, the military might needed to do all of the above. Thus, the 2008 battle is re-joined: is Romney's evocation of Ronald Reagan's "Peace Through Strength" the right approach for the $21^{\text {st }}$ century? Or is Obama's pledge to "concentrate on the most serious threats facing our country, promote our values, and improve our standing in the world?"

It is worth noting here that this battle is playing out within the GOP as well - and that its shape there is at least as interesting and consequential as what is going on in the general election debate. The candidate preferred by the internationalist, realist GOP foreign policy establishment, Jon Huntsman, former U.S. ambassador to China, failed emphatically to gain traction with Republican primary electorates. His habit of speaking Mandarin at debates, it was noted, did not help. Much has been written about the discomfort of the GOP foreign policy mainstream, with its senior leaders slow to endorse Romney and its rank-and-file leaking to the New York Times about their struggles for campaign influence against former Bush UN Ambassador John Bolton, the bête noire of internationalists in both parties.

But a substantial part of the closing ranks around Romney comes out of fear of the Ron Paul wing of the Republican party, and the discomfiting fact that Paul's calls for ending the wars, eschewing military action against Iran, and reexamining all foreign aid, including Israel's, draw enthusiastic response from a significant chunk of the GOP base. Florida Senator and rising GOP star Marco Rubio has sought to stake out for himself the international statesman role being vacated by Senator Richard Lugar - defeated in a primary by a candidate who made his internationalism a liability. Rubio launched himself into the foreign policy elite with twin speeches at the Brookings Institution in Washington and the Council on Foreign Relations in New York - in which he spent as much time criticizing unnamed opponents of engagement within his own party as he did differing with Obama's approaches.

\section{National Security as Shorthand for Leadership}

Of course, even with fundamental fissures within and between the parties about the nature of the U.S. role in the world, foreign policy per se moves only a very small number of voters directly - particularly during hard economic times. But with each campaign interested in making this election a referendum on leadership - Romney as a strong managerial executive, and Obama as holding a strong track record of steady-hand-on-thetiller-through-rough-seas - using national security to make the case, and undermine the other side's, has proven irresistible.
Obama is in a position not enjoyed by a Democratic incumbent since JFK, or perhaps Truman - he is seen as tougher and more successful on the nation's key national security challenges than his opponent or his predecessor. His team has been eager to trumpet this both on its own merit and as a way to make the case about other kinds of leadership - in Vice President Joe Biden's words, "Bin Laden is dead and General Motors is alive."

Republicans, whatever their views on the substance of national security, have been understandably reluctant to cede the political advantage they held for so long. Last year, conservative strategists Karl Rove and Ed Gillespie explicitly advised (http://www.foreignpolicy.com/articles/2012/ 02/27/how to beat_obama?page=full) the GOP candidates to go after Obama on national security.

In an American election focused on a lousy economy and high unemployment, conventional wisdom holds that foreign policy is one of Barack Obama's few strong suits. But the president is strikingly vulnerable in this area. The Republican who leads the GOP ticket can attack him on what Obama mistakenly thinks is his major strength by translating the center-right critique of his foreign policy into campaign themes and action...The Republican nominee should use the president's own words and actions to portray him as naive and weak on foreign affairs. Obama's failed promises, missed opportunities, and erratic shifts suggest he is out of touch and in over his head.

Rove's strategic guidance has bipartisan parentage - and a successful track record. It is worth remembering that not since the Reagan era has a presidential candidate's national security background proven to be much electoral help. In the last five presidential elections, the candidate who on paper looked much stronger on national security lost and was made by his opponent to feel the issue a significant liability with swing voters. (World War II heroes George H.W. Bush and Bob Dole; Al Gore, who served honorably in Vietnam and had been involved in foreign policy in the Senate and 8 years as Vice President; decorated Vietnam veteran John Kerry; and Vietnam POW John McCain.)

Thus we have the GOP counter-attack, begun in the primaries and now continued by Romney: Obama is weak, even an appeaser, on Iran and Russia. He "apologizes" for the United States and "doesn't understand" America's greatness or its sources. He fails to support our allies - Israel, Taiwan, the smaller NATO allies of central Europe.

These attacks have not had much effect on public views on the issues - in March 2009, for example, after 10 solid months of primary rhetoric about the need for urgent action against Iran, the public still preferred (http://www.people-press.org/ question-search/?qid=1806670\&pid=51\&ccid=50\#top) to wait on the effects of economic sanctions, by $47-40 \%$. But 
for political purposes they don't have to - and perhaps more than usual, the vehement rhetoric masks policy differences that are very small. Though the two candidates represent different worldviews, as noted above, the realities of the U.S. geopolitical position, and economic weakness, mean that on the key issues the GOP has chosen to raise, Romney in office might well find himself constrained to follow Obama's lead. His voters now firmly support a pullout from Afghanistan as well - and so, to the despair of the party's neoconservative intellectuals, his firm policy pledges on Afghanistan are limited to re-visiting Obama's strategy and "listening to the generals." On Iran, likewise, Romney's policy advisers have surely noticed the U.S. military's opposition to an attack even if his political advisers have not. Bipartisan defense experts are writing with confidence that Pentagon spending will continue to trend down in years to come - Romney's plans to build more ships and add 100,000 ground troops notwithstanding.

\section{The Foreign as Source of Fear}

Finally, as in every Presidential campaign in a down economy, international issues will feature as a focus of the fear and distress Americans are feeling about their economic prospects. This comes up most obviously in relation to China and economic issues - as it has for decades, with China taking over the place Japan held in 1970s and 1980s American imaginations. The challenger - regardless of party - makes promises to get "tough" that his advisers quietly (or not so quietly, as when Austan Goolsbee disavowed candidate Obama's talk of renegotiating NAFTA in 2008) acknowledge are unworkable. The incumbent explains the advantages of trade, and grits his teeth. The argument has a regional valence, as regions that have benefited from hightech exports and from the import business will respond differently from the former strongholds of the textile and manufacturing industries. With this year's swing states falling in both categories (Florida, Virginia, Ohio, North Carolina, Colorado), it seems likely to bubble along quietly without becoming a major national theme. Scaremongering about broader Chinese influence, whether through alleged weakness in cybersecurity (a Romney accusation) or allegations that funders are excessively foreign-influence (a charged leveled against GOP donor Sheldon Adelson for his Macau casino holdings, by Senator McCain) will also play a role, as it did in the 2010 midterms.

Since 2008, Islamophobia has emerged as another strain in our national politics. Popular anxieties that arose after 9-11 had quietly been fanned by localized "anti-sharia" movements, mobilizing against the purported threat of Islamic family law being imposed on American communities. The economic downturn, the eruption onto our television screens of revolutions and protests across the Arab world, and the anxiety over policy developments and the shifting US role in the Middle East - not to mention the election of a president with dark skin and a Muslim name - have combined to bring the issue to national prominence. A small group of activists created the 2009 protests around the Park51 Islamic Center in lower Manhattan and have had their issues raised in Congressional hearings sponsored by Representative Peter King. The 2010 midterms saw explicitly Islamophobic ads run by a number of federal campaigns, none of them successful - but the story is different at the state and local level, where antisharia ordinances and amendments continue to be successful, and state level candidates have adopted the issue and worryingly Islamophobic messaging.

Islamophobia and other cultural issues are unlikely to play explicitly in the 2012 presidential race. Because Mitt Romney is himself a member of an often-reviled minority group, the Church of Jesus Christ of Latter-Day Saints, he personally will not pick up the attack. In the primaries, however, others did - perhaps most notoriously, Herman Cain said that Muslims should have to take loyalty oaths and might not be appropriate for Cabinet service. Downticket, the issue will arise explicitly - and when rhetoric is heard about the President "not understanding" America, it may well link back in some voters' minds to a narrative about foreignness, threat and alien values.

Of course, that narrative has been a core one in Americans' political discussion of national security since our founding, separated by oceans and deserts, convinced of our uniqueness and perhaps our superiority. We have indulged in it safely, and used it to prop up ideologies of all stripes and assumed (often wrongly) that it signifies a certain familiarity with the limits of American public support for plans to remake the world in our image.

Now, of course, our politics are not separated from policy (if indeed they ever were) and tweets, emails, wire transfers and cheap flights run right over the water's edge. The way we use foreign policy in elections may tell us something about what we are most afraid of - and, by telling that to the rest of the world, it may constrain the abilities of whomever is elected to do anything about our fears.

Heather Hurlburt is the Executive Director of the National Security Network. She served in the Clinton Administration as Special Assistant and Speechwriter to President Clinton, and has also worked on U.S. foreign policy in the State Department, Capitol Hill, and overseas. 